\title{
Preparation, Characterization and Utilization of the Suspended- Keratin Based Binder in Pigment Printing of Man-Made Fibers
}

\author{
M. Abou Taleb ${ }^{1}$, K. Haggag ${ }^{2}$, Tahia B. Mostafa ${ }^{3}$, A. Abou El-Kheir ${ }^{1}$, and H. El-Sayed ${ }^{\text {* }}$ \\ ${ }^{1}$ Proteinic and Man-made Fibres Department, National Research Centre, Dokki, Cairo, Egypt. \\ ${ }^{2}$ Dyeing, Printing and Textile Auxiliaries Department, National Research Centre, Dokki, Cairo, Egypt. \\ ${ }^{3}$ College of Women for Arts, Science and Education, Ain Shams University, Heliopolis, Cairo, Egypt.
}

\begin{abstract}
CUSPENDED keratin-based binder (Su-KBB) was prepared from renewable cheap natural resources; namely, coarse Egyptian wool fleece or feather to replace the commercially used synthetic binders required for pigment printing technique. Most of the commercially used binders are relatively expensive, environmentally unfriendly and imported from abroad. The said Su-KBB was prepared using safe chemicals, reagents and solvents for extraction of keratin from its natural resources. Chemical, physical, and thermal characteristics of the said binder were assessed and compared with the starting material.

The prepared Su-KBB was utilized as a cheap eco-friendly binder in printing of polyester, poly acrylonitrile, viscose as well as polyester/viscose, and polyester/acrylic blends. Different concentrations of Su-KBB were prepared, and different amounts were added to the pigment paste in presence or absence of a cross-linker. The color strength of the printed fabrics and their fastness properties to light, washing, and perspiration $n$ were evaluated. The effect of the used binder on bending stiffness of the printed fabrics was assessed. Results of this study showed that printed fabrics using Su-KBB exhibit almost similar color strength values as the commercial binder (CB). The rubbing fastness of Su-KBB on using cross-linker was acceptable and comparable with that of the $\mathrm{CB}$.
\end{abstract}

Keywords: Suspended-keratin, Binder, Pigment printing, Man-made fibers, Egyptian wool, Feather

\section{Introduction}

Textile printing is the branch of the wet processing industry and is extensively used for all the fibers and variety of fabrics as well as fashion. Mostly, printing is some form of dyeing in which the colors are applied to specific areas instead of the entire fabric. To restrict the color to the design area, it is contained in a paste with a thickening agent which may be a natural or synthetic polymer. These polymeric products include such various products as plant gums, seaweed alginate, starches and poly acrylics. After printing, the fabric is dried \& then the color is fixed by heat for a short time. During steaming process and under the action of heat and moisture, the dye molecules penetrate the printed areas of the fabric and are also fixed. After steaming, the printed fabrics are washed to remove the thickener and other chemicals. The pigments are unique because binders and thickeners are sufficiently soft to avoid the expensive washing and drying processes [1]. Printing paste contains pigments, thickeners, binders, and auxiliaries. Binders are high molecular weight film forming agents produced by the polymerization of simple intermediates initially present in the paste in a homogeneous, dissolved or dispersed state. After evaporation of the solvent, heating produces a thin film. The film encloses the pigment particles and adheres to the fiber. The rubbing, washing and perspiration fastness of the printed fabrics are, the contribution of reactive groups in the macromolecule enables linking to occur within the binder after film formation by a simple heat treatment thereby improving its resistance to chemical and physical actions. Cross-linking increases the rubbing, washing and perspiration

\footnotetext{
* corresponding author e-mail: hosam@trdegypt.org 
fastness properties, but it affects the handle of the final print [2]. When a binder molecule has no self-cross-linking groups, an additional crosslinking agent having at least two reactive groups is used in the binder system. Cross-linking agents are used in small quantities even when the binder has self-cross-linking groups, since they help to improve the fastness properties.

Wool, as well as, feather is a protein fiber and as such consist of the elements $\mathrm{C}, \mathrm{H}, \mathrm{O}, \mathrm{N}$, and $\mathrm{S}$ [3]. Proteins are natural polymers of high relative molecular mass. They are very widespread in nature, being essential components of animal tissue viz. Sheep wool, camel hair and poultry feathers or plant tissue viz. soy protein from soybean, wheat gluten and zein from corn. The basic structural units of proteins are $\alpha$-amino acids, which have the general formula [4]: $\mathrm{H}_{2} \mathrm{~N}-\mathrm{CH}(\mathrm{R})-\mathrm{COOH}$. It has been proven by mass spectral analysis that the molecular mass of soluble protein lies between 2-9 $\mathrm{kDa}$ and the number of amino acid residues along any oligopeptide chain is at least 20 amino acid residues [5].

The present study aims at preparation of suspended-keratin from renewable cheap natural resources through a clean, safe and environmentally friendly way. The prepared suspended-keratin is evaluated as a binder in pigment printing of man-made fabrics and their blends to replace the unsafe highly expensive commercial binder.

\section{Materials and Methods}

\section{Materials}

$100 \%$ scoured polyester fabric, $100 \%$ acrylic fabric, $100 \%$ viscose fabric, polyester/viscose (60/40) fabric and polyester/acrylic (60/40) fabrics were supplied by Misr Co. for Spinning and Weaving, El-Mehalla El-Kubra, Egypt.

Raw Egyptian wool fleece (Barki) and chicken feather was collected from local market.

\section{Pigments and Reagents}

Two pigments, namely Print M.D. Blue 2G and Red GRL were supplied by DAICO for the Chemical Industry, Egypt. The commercial binder SME-2 (Acrylate -based), and thickener Daicothick 1600 (based on polyacrylate) supplied by DAICO for the Chemical Industry, Egypt were used in this study. Sodium hydroxide and thiourea were purchased from El-Nasr Pharmaceutical Chemicals Company, Egypt. Urea was supplied by Merck, Germany. Glutardialdehyde (25\% aqueous solution $\mathrm{w} / \mathrm{w}$ ) was purchased from Aldrich, Steinheim, Germany. All other chemicals used in this investigation are of laboratory grade.

\section{Methods \\ Scouring}

Coarse wool or chicken feather were scoured using $2 \mathrm{~g} / 1$ sodium carbonate and $1 \mathrm{~g} / 1$ nonionic detergent at $60{ }^{\circ} \mathrm{C}$ for $15 \mathrm{~min}$ followed by thorough rinsing with cold water then squeezed and finally air dried at ambient temperature.

\section{Preparation of suspended-keratin binders}

Coarse wool and chicken feather were dissolved in a mixture of $2 \% \mathrm{NaOH}, 8 \%$ urea and $6.58 \%$ thiourea for $10 \mathrm{~min}$ at $50{ }^{\circ} \mathrm{C}[6,7]$.

The obtained soluble keratin was then precipitated in a coagulating bath containing $6 \% \mathrm{H}_{2} \mathrm{SO}_{4}$ and $12 \% \mathrm{NH}_{4} \mathrm{Cl}(\mathrm{w} / \mathrm{v})$ [8], and the precipitate was filtered through polyester cloth and washed extensively with distilled water until $\mathrm{pH}$ 7. The precipitate was then left to dry overnight and then ground to a fine powder.

$5 \mathrm{~g}$ of the powdered keratin was suspended in $25 \mathrm{ml}$ distilled water under stirring with the ultrasonic homogenizer for about $5 \mathrm{~min}$. $2 \mathrm{~g}$ urea dissolved in $25 \mathrm{ml}$ distilled water was added to the mixture with stirring for another $5 \mathrm{~min} .0 .2 \mathrm{~g}$ $\mathrm{NaOH}$ dissolved in $25 \mathrm{ml}$ distilled water and then added to the previous mixture and continues stirring with the homogenizer for extra 5 min to have suspended solution of keratin (the keratin concentration in the suspension was about $3 \%$ ).

The previous steps were repeated to obtain a suspension with keratin concentration $6 \%$ and $10 \%$. The pigment pastes were prepared using the keratin suspension prepared in different concentrations $(3 \%-6 \%-10 \%)$.

\section{Printing pastes}

The printing pastes were prepared according to the formulation given in Table 1. Ammonia, urea, ammonium phosphate monobasic and the binder were mixed together. The thickener was then introduced and the paste was stirred using a high shear mixer for $10 \mathrm{~min}$ to allow full viscosity to develop. The pigment was then added to the mixture with stirring using a high shear mixer for $15 \mathrm{~min}$. Different amounts of the suspended keratin were added to the pigment paste $(5-10-15 \%)$. 
The pigment pastes were also prepared using $2 \%$ gluterdialdhyde as a crosslinker for the suspended-keratin based binder on the fabric.

TABLE 1. Composition of the pigment paste

\begin{tabular}{|lc|}
\hline Components & $\begin{array}{c}\text { Weight (in } \\
\text { grams) }\end{array}$ \\
\hline 1- Ammonia (25\%) & 0.5 \\
2- Su-KBB & $(5-10-15)$ \\
3- Thickener (Alcoprint PTP) & 3 \\
4-Diammonium hydrogen & 0.5 \\
phosphate & 4 \\
5- Urea & 5 \\
6- Pigment & $(82-77-72)$ \\
7- water & $100 \mathrm{~g}$ \\
Total & \\
\hline
\end{tabular}

\section{Printing Technique}

All printing pastes were applied to the selected fabrics using the flat screen printing technique.

\section{Print Fixation}

Prints were air dried, and then fixed at different temperatures $\left(140^{\circ} \mathrm{C}-150^{\circ} \mathrm{C}-160^{\circ} \mathrm{C}\right)$ for different periods of time ( $3-4-5 \mathrm{~min})$ in an automatic thermostatic oven (Wermer Mathis Co., Switzerland).

\section{Measurements}

\section{Color Strength Measurements}

The K/S of the printed fabrics were measured using a UV-Vis spectrophotometer with pulsed xenon lamps as light source (UltraScan Pro, Hunter Lab, USA) $10^{\circ}$ observer with D65 illuminant, $\mathrm{d} / 2$ viewing geometry and measurement area of $2 \mathrm{~mm}$. The measurements of printed fabrics with blue pigment were occurred at $\lambda_{560} \mathrm{~nm}$ and those printed with red pigment occurred at $\lambda_{510}$ wavelength. The corresponding color strength value (K/S) was assessed by applying the Kubelka Munk [9] (Equation 1).

$$
\mathrm{K} / \mathrm{S}=(1-\mathrm{R})^{2} / 2 \mathrm{R}-(1-\mathrm{R} 0)^{2} / 2 \mathrm{RO}
$$

Where $\mathrm{R}, \mathrm{R}_{\mathrm{O}}$ is the decimal fraction of the reflection of the colored fabric, $\mathrm{K}$ is the absorption coefficient and $\mathrm{S}$ is the scattering coefficient.

\section{Fastness Properties \\ Colorfastness to Rubbing}

The wet and dry color fastnesses to rubbing of the printed samples were determined according to AATCC test method 8, (1989) [10].

Colorfastness to Washing

The colorfastness to washing was determined according to the AATCC test method 36, (1972) [11]. using Lunder Ometer. The washing fastness was assessed using the Grey Scale reference for color change.

\section{Colorfastness to perspiration}

Colorfastness to perspiration was determined with acidic and alkaline perspiration solutions according to AATCC test method 15, (1989) [12]. The effect on the color of the test specimen was expressed and defined by reference to Grey Scale for color change.

\section{Colorfastness to Light}

Colorfastness to light was determined according to AATCC test method (16 A-1989). Evaluation was established using blue scale as reference of color change [13].

\section{Stiffness Properties}

Stiffness of printed and unprinted samples was determined according to ASTM test method D 1388 - 96 using the cantilever apparatus [14].

Rheological Properties of the Printing Pastes

The rheological properties of the pastes were measured using Programmable Rheometer (Model DV III), from Brookfield Engineering Labs. Stoughton, MA, U.S.A.

\section{Water absorbency of the binder films}

Films of suspended-keratin based binder and the commercial binder were prepared by pouring the binders in Petri dishes and left to dry in air. The formed films were cured for $5 \mathrm{~min}$ at $150{ }^{\circ} \mathrm{C}$, then left to cool at room temperature for $24 \mathrm{hr}$. The weight of each binder film was determined (W). The films were then immersed in distilled water for different intervals of time $(6,12,24$ and $48 \mathrm{hr}$ ) at room temperature. The surface water was then removed by a filter paper and the swollen film was reweighed (W1).The water absorbency (\%) was calculated according to Eq. 2 [15].

Water absorbency $(\%)=\frac{\text { W1 }-\mathrm{W}}{\mathrm{W}} \times 100$ Eq. 2

Where:

$\mathrm{W}=$ the weight of the original sample $\mathrm{W} 1=$ the weight of the swollen sample

\section{TGA and DSC Measurement}

Thermo gravimetric analysis (TGA) and differential scanning calorimetry (DSC) were measured using SDT 
Q 600 with Rate of heating $10^{\circ} \mathrm{C} / \mathrm{min}$.

Infrared (IR) Spectrometry

Infrared spectroscopy was carried out for the suspended-keratin based binder (Su-KBB) on JASCO FT/IR 6100, Japan, in range $4000-400$ $\mathrm{cm}^{-1}$.

\section{Elemental analysis}

The amounts of carbon, hydrogen, nitrogen and sulphur in the suspended-keratin based binder were assessed using the device Elementar CHNS Analyser, Model Vario EL III, Germany.

\section{Results and Discussion}

In order to attain the optimum conditions of pigment printing, different concentrations of suspended-keratin based binder (Su-KBB) were prepared with different keratin concentration. Different concentrations of the Su-KBB under different thermo-fixation temperature and time were adopted, and their influence on the color strength and the fastness properties were monitored. The pigment used for this study was M.D. Blue $2 \mathrm{G}$ with the structural formula shown in Structure 1.<smiles>[R]OC(=O)Nc1cc(C(=O)O[R])c(N)c2c1C(=O)c1ccccc1C2=O</smiles>

Effect of different concentrations of keratin in the $\mathrm{Su}-\mathrm{KBB}$, on the fastness properties of the printed fabrics

Different suspended-keratin based binders were prepared containing different concentrations of keratin. The effect of these suspensions on the color strength and rubbing properties were tabulated in Table 2.

Data of this table showed that the color strength of the used concentrations is almost comparable to each other although the rubbing fastness is more enhanced at the concentration $6 \%$ and $10 \%$ where the lower concentration of keratin caused bleeding of the color on the fabric due to the limited number of functional groups required to bind the film containing pigment to the fabric and hence the rubbing properties were unsatisfactory.

Effect of different concentrations of Su-KBB in the pigment paste on the fastness properties of the printed fabrics

The effect of different concentrations of $\mathrm{Su}-\mathrm{KBB}$ on the color strength and the fastness properties of the printed fabrics were studied and the results of this study were tabulated in Table 3.

Data of this table showed that, the color strength and rubbing fastness is better on using $15 \%$ concentration of the $\mathrm{Su}-\mathrm{KBB}$ in the pigment paste. Where the concentrations $10 \%$ and $15 \%$ have comparable results only slightly differ in the results of color strength and rubbing fastness. On

TABLE 2. Effect of different concentrations of keratin in the Su-KBB on the color strength and rubbing properties (using $10 \%$ of the pigment paste and thermo-fixation temperature $140^{\circ} \mathrm{C}$ for $4 \mathrm{~min}$ ).

\begin{tabular}{|c|c|c|c|c|}
\hline \multirow{2}{*}{$\begin{array}{l}\text { Concentration of } \\
\text { keratin in Su-KBB }\end{array}$} & \multirow{2}{*}{ Printed substrate } & \multirow{2}{*}{$\mathrm{K} / \mathrm{S}$} & \multicolumn{2}{|c|}{ Rubbing } \\
\hline & & & Dry & Wet \\
\hline \multirow{5}{*}{$3 \%$} & Acrylic & 13.88 & 2 & 2 \\
\hline & Polyester & 13.63 & $2-3$ & 2 \\
\hline & Viscose & 14.7 & $2-3$ & 2 \\
\hline & Polyester / viscose & 11.73. & 3 & $2-3$ \\
\hline & Polyester / Acrylic & 11.86 & $2-3$ & 2 \\
\hline \multirow{5}{*}{$6 \%$} & Acrylic & 15.94 & $2-3$ & $1-2$ \\
\hline & Polyester & 11.5 & $2-3$ & $1-2$ \\
\hline & Viscose & 14.73 & 3 & $2-3$ \\
\hline & Polyester / viscose & 12.32 & 3 & $2-3$ \\
\hline & Polyester / Acrylic & 12.02 & $2-3$ & 2 \\
\hline \multirow{5}{*}{$10 \%$} & Acrylic & 13.5 & $2-3$ & 2 \\
\hline & Polyester & 10.8 & 2 & $1-2$ \\
\hline & Viscose & 14.2 & 3 & $2-3$ \\
\hline & Polyester / viscose & 9.71 & $2-3$ & 2 \\
\hline & Polyester / Acrylic & 11.54 & $2-3$ & 2 \\
\hline
\end{tabular}

Egypt.J.Chem. Special Issue (2017) 
the other hand the lower concentration i.e. $5 \%$ caused bleeding of the colorant on the fabric and hence decreasing both of the color strength and the rubbing properties which might be explained by the fact that $5 \% \mathrm{Su}-\mathrm{KBB}$ in the pigment paste provides less functional group to bind the keratin-pigment composite film to the fabric. The proposed mechanism of Su-KBB with M.D. blue $2 \mathrm{G}$ pigment was shown in the (scheme reaction 1$)$.

Effect of thermo-fixation temperature on the fastness properties of the printed fabrics

The influence of fixation temperatures on the color strength and rubbing fastness of the printed fabrics were studied to reach the proper temperature for thermo-fixation. Results of this study were tabulated in Table 4. Data of this table showed that, thermo-fixation of the printed samples by curing at $140^{\circ} \mathrm{C}$, gave higher $\mathrm{K} / \mathrm{S}$ values and rubbing fastness than those samples cured at lower temperature $130^{\circ} \mathrm{C}$ or higher temperature at $150{ }^{\circ} \mathrm{C}$. This result can be correlated to the data of Table 10, which prevailed that the initial decomposition temperature of the $\mathrm{Su}-\mathrm{KBB}$ is around $130^{\circ} \mathrm{C}$. That's why any further increase in temperature causes increase in the decomposition process which affects the binding ability of the protein as a long chain polymer [16].

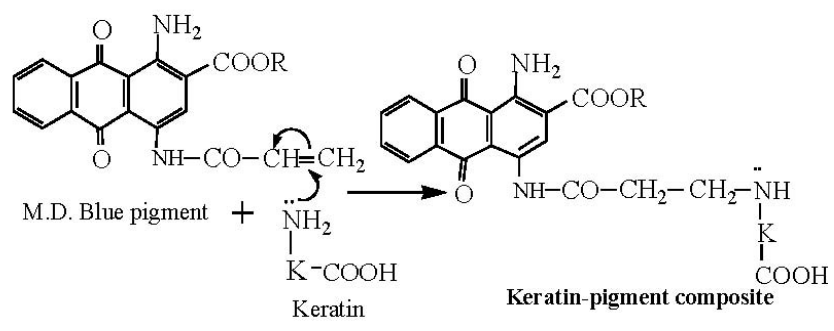

Scheme reaction 1. Proposed reaction mechanism between M.D. Blue 2G pigment and keratin.

TABLE 3. Effect of different concentrations of Su-KBB on the color strength and rubbing properties of the printed fabrics (using Su-KBB with $6 \%$ concn. at $140^{\circ} \mathrm{C}$ for $4 \mathrm{~min}$ ).

\begin{tabular}{|c|c|c|c|c|}
\hline \multirow{2}{*}{$\begin{array}{c}\text { Concentration Su- } \\
\text { KBB }\end{array}$} & \multirow{2}{*}{ Substrate } & \multirow{2}{*}{$\mathbf{K} / \mathbf{S}$} & \multicolumn{2}{|c|}{ Rubbing } \\
\hline & & & Dry & Wet \\
\hline \multirow{5}{*}{$5 \%$} & Acrylic & 13.42 & 2 & $1-2$ \\
\hline & Polyester & 12.92 & $2-3$ & 2 \\
\hline & Viscose & 15.49 & $2-3$ & 2 \\
\hline & Polyester / viscose & 11.47 & 3 & $2-3$ \\
\hline & Polyester / Acrylic & 10.27 & $2-3$ & 2 \\
\hline \multirow{5}{*}{$10 \%$} & Acrylic & 15.94 & $2-3$ & $1-2$ \\
\hline & Polyester & 11.5 & $2-3$ & $1-2$ \\
\hline & Viscose & 14.73 & 3 & 2 \\
\hline & Polyester / viscose & 12.32 & 3 & $2-3$ \\
\hline & Polyester / Acrylic & 12.02 & $2-3$ & 2 \\
\hline \multirow{5}{*}{$15 \%$} & Acrylic & 16.3 & $2-3$ & 2 \\
\hline & Polyester & 11.19 & $2-3$ & 2 \\
\hline & Viscose & 18.42 & 3 & $2-3$ \\
\hline & Polyester / viscose & 15.54 & 3 & $2-3$ \\
\hline & Polyester / Acrylic & 12.74 & $2-3$ & 2 \\
\hline
\end{tabular}


TABLE 4. Effect of different thermo-fixation temperature on the color strength and rubbing properties of the printed fabrics (using $15 \%$ of $\mathrm{Su}-\mathrm{KBB}$ with $6 \%$ keratin conen. for $4 \mathrm{~min}$ ).

\begin{tabular}{|c|c|c|c|c|}
\hline \multirow{2}{*}{$\begin{array}{c}\text { Fixation } \\
\text { temperature }\end{array}$} & \multirow{2}{*}{ Substrate } & \multirow{2}{*}{$\mathrm{K} / \mathrm{S}$} & \multicolumn{2}{|c|}{ Rubbing } \\
\hline & & & Dry & Wet \\
\hline \multirow{5}{*}{$130^{\circ} \mathrm{C}$} & Acrylic & 13.1 & 2 & $1-2$ \\
\hline & Polyester & 11.3 & $2-3$ & 2 \\
\hline & Viscose & 15.2 & $2-3$ & 2 \\
\hline & Polyester / viscose & 13.5 & 3 & $2-3$ \\
\hline & Polyester / Acrylic & 11.6 & $2-3$ & 2 \\
\hline \multirow{5}{*}{$140^{\circ} \mathrm{C}$} & Acrylic & 16.3 & $2-3$ & 2 \\
\hline & Polyester & 11.19 & $2-3$ & 2 \\
\hline & Viscose & 18.42 & 3 & $2-3$ \\
\hline & Polyester / viscose & 15.54 & 3 & $2-3$ \\
\hline & Polyester / Acrylic & 12.74 & $2-3$ & 2 \\
\hline \multirow{5}{*}{$150^{\circ} \mathrm{C}$} & Acrylic & 12.45 & $2-3$ & $1-2$ \\
\hline & Polyester & 10.5 & $2-3$ & $1-2$ \\
\hline & Viscose & 16.5 & $2-3$ & $2-3$ \\
\hline & Polyester / viscose & 13.6 & 3 & $2-3$ \\
\hline & Polyester / Acrylic & 10.7 & $2-3$ & $1-2$ \\
\hline
\end{tabular}

TABLE 5. Effect of different thermo-fixation time on the color strength and rubbing properties of the printed fabrics (using $15 \%$ of $\mathrm{Su}-\mathrm{KBB}$ with $6 \%$ keratin conc. at $140^{\circ} \mathrm{C}$ ).

\begin{tabular}{|c|c|c|c|c|}
\hline \multirow[b]{2}{*}{ Fixation time } & \multirow[b]{2}{*}{ Substrate } & \multirow[b]{2}{*}{$\mathbf{K} / \mathbf{S}$} & \multicolumn{2}{|c|}{ Rubbing } \\
\hline & & & Dry & Wet \\
\hline \multirow{5}{*}{$3 \mathrm{~min}$} & Acrylic & 13.6 & 2 & $1-2$ \\
\hline & Polyester & 12.3 & $2-3$ & $1-2$ \\
\hline & Viscose & 14.2 & $2-3$ & 2 \\
\hline & Polyester/viscose & 12.6 & 3 & $2-3$ \\
\hline & Polyester / Acrylic & 10.8 & $2-3$ & 2 \\
\hline \multirow{5}{*}{$4 \mathrm{~min}$} & Acrylic & 16.3 & $2-3$ & 2 \\
\hline & Polyester & 11.19 & $2-3$ & 2 \\
\hline & Viscose & 18.42 & 3 & $2-3$ \\
\hline & Polyester / viscose & 15.54 & 3 & $2-3$ \\
\hline & Polyester / Acrylic & 12.74 & $2-3$ & 2 \\
\hline \multirow{5}{*}{$5 \mathrm{~min}$} & Acrylic & 12.5 & $2-3$ & $1-2$ \\
\hline & Polyester & 11.2 & $2-3$ & $1-2$ \\
\hline & Viscose & 16.8 & $2-3$ & $2-3$ \\
\hline & Polyester/viscose & 14.3 & 3 & $2-3$ \\
\hline & Polyester / Acrylic & 10.7 & $2-3$ & $1-2$ \\
\hline
\end{tabular}

Effect of thermo-fixation time on the fastness properties of the printed fabrics

Different fixation times were also studied to reach the optimum conditions for the printing process. The effect of fixation time on color strength and fastness properties was studied and the results were monitored in Table 5. Data of this table 
showed that, the K/S values and rubbing fastness increased with increasing time of thermo-fixation. This may be due to the enhanced extent of crosslinking between the binder and the fabric by time. Further increase in fixation time led to declining in the $\mathrm{K} / \mathrm{S}$ values and fastness properties of the printed fabrics. This may be due to thermal degradation of $\mathrm{Su}-\mathrm{KBB}$ by exposing to relatively severe conditions i.e. high temperature for prolonged time.

Data of Tables 2-5 showed that, on reaching the optimum conditions the color strength values of all the fabrics are almost comparable to each other. This could be explained in terms of the triboelectric series, which implies that upon rubbing fabrics like, polyester and polyacrylonitril with other materials, their tendency to attract electrons increase [17]. Thus, it was easy for the lone pair of electrons, of the secondary amino group of the prepared Su$\mathrm{KBB} /$ pigment composite, to be attracted to the surface of the polyester and acrylic fabric. While fabrics like viscose is neutral and binds with the said composite chemically by virtue of its hydroxyl groups (c.f. Scheme reaction 2). Consequently, it was obvious from data of Tables 2-5 that rubbing fastness of the printed viscose fabrics and its blend was better than those of polyester and acrylic samples and their blends. It was also noticed from

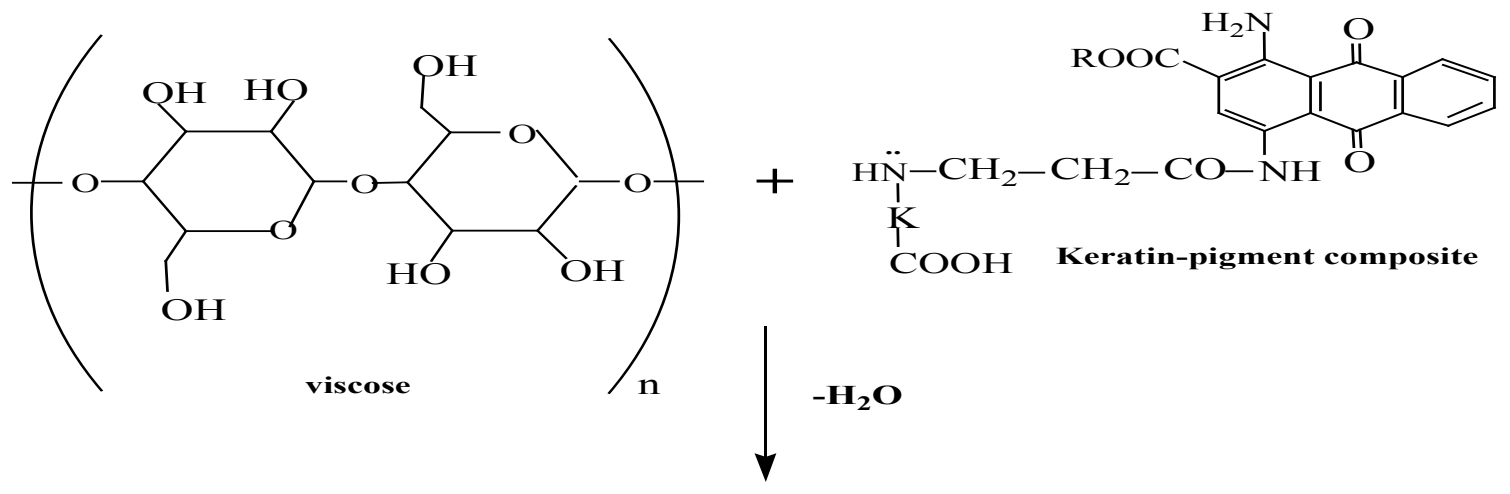<smiles>[R]OC(=O)C1=C(N)C(=O)c2ccccc2C1=O</smiles>

Scheme reaction 2. proposed reaction mechanism between keratin-pigment composite and viscose.
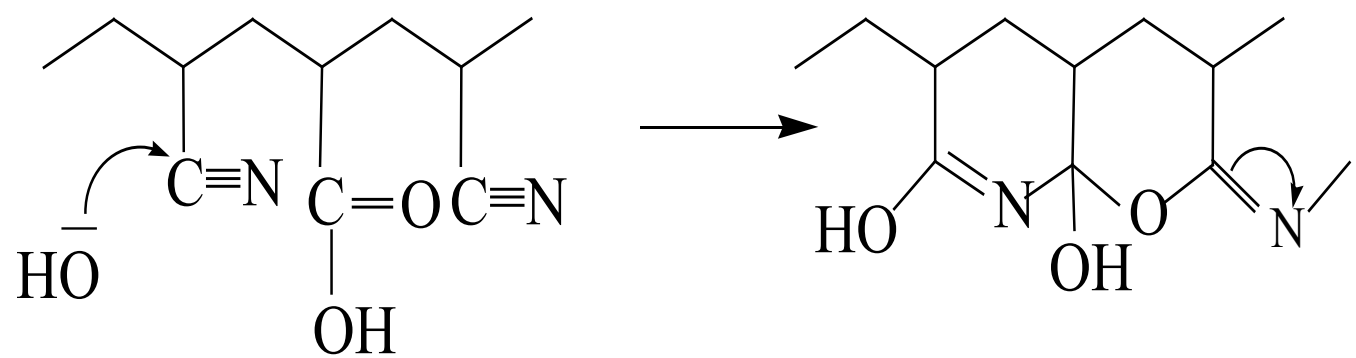

Scheme reaction 3. Cyclization mechanism of poly acrylonitrile. 
the previous tables that the color strength of printed acrylic fabrics is higher than that of the polyester fabric. This might be due to cyclization reaction of the carboxylic groups present in poly acrylonitrile fabric [c.f. Scheme reaction 3] [18,19]. This leads to decrease the number of carboxylic groups which imparts the negative character on poly acrylonitrile fabric. Consequently, the tendency of the keratinpigment composite formed in Scheme 1 to be attracted by its lone pair of electrons to the surface of the fabric increase, thus color strength on the polyacrylonitrile fabrics increase.

Thus, it is obvious from Tables 2-5 that the optimum conditions of using suspended-keratin as a binder in the pigment printing process were $15 \%$ of the Su-KBB (with $6 \%$ keratin), at $140^{\circ} \mathrm{C}$, for $4 \mathrm{~min}$. These optimum conditions were then adopted in printing of man-made fibers and their blends with and without a cross-linking agent.

\section{Effect of cross-linking agent}

Glutardialdhyde (GLU) was used as a crosslinker for the prepared $\mathrm{Su}-\mathrm{KBB}$ in the pigment paste to improve its durability to wet treatment and thus enhance the fastness properties of the printed samples. Results of this study were tabulated in Table 6. Data of this table showed that, the K/S values and fastness properties of the printed samples in presence of glutardialdhyde as a cross linker are higher than those in absence of it.

This may be rationalized in terms of the fact that glutardialdhyde causes cross-linking of the prepared $\mathrm{Su}-\mathrm{KBB}$ by virtue of the active sites along keratin macromolecules [20]. Hence,

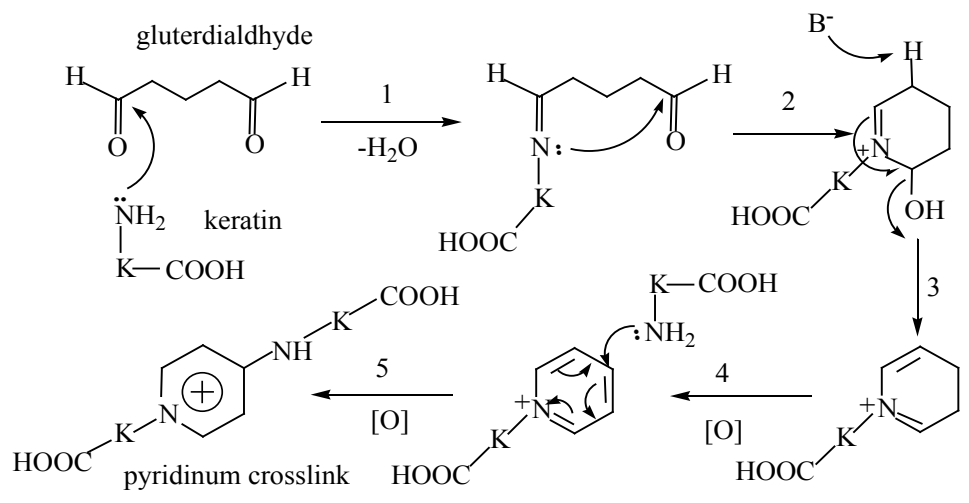

Scheme reaction 4. Mechanism of formation of pyridinium crosslink.

TABLE 6. Effect of cross-linkers on the color strength and the fastness properties of the printed fabrics using print M.D. blue 2G

\begin{tabular}{|c|c|c|c|c|c|c|c|c|c|c|c|c|c|c|c|c|}
\hline \multirow{4}{*}{$\begin{array}{c}\text { Preparation } \\
\text { condition of } \\
\text { the pigment } \\
\text { paste }\end{array}$} & \multirow{4}{*}{ Fabric } & \multirow{4}{*}{$\mathbf{K} / / \mathbf{S}$} & \multirow{4}{*}{$\begin{array}{c}\text { Stiffness } \\
\text { of the } \\
\text { printed } \\
\text { fabric }\end{array}$} & \multirow{4}{*}{$\begin{array}{l}\text { Stiffness } \\
\text { of the } \\
\text { unprinted } \\
\text { fabric }\end{array}$} & \multirow{4}{*}{$\begin{array}{l}\text { Light } \\
\text { fastness }\end{array}$} & \multicolumn{2}{|c|}{ Rubbing } & \multicolumn{3}{|c|}{ Washing } & \multicolumn{6}{|c|}{ Perspiration } \\
\hline & & & & & & \multirow{3}{*}{ Dry } & \multirow{3}{*}{ Wet } & \multicolumn{2}{|c|}{ Staining } & \multirow{3}{*}{ Alter } & \multicolumn{3}{|c|}{ Acidic } & \multicolumn{3}{|c|}{ Alkaline } \\
\hline & & & & & & & & \multirow[b]{2}{*}{$\mathbf{s t}^{*}$} & \multirow[b]{2}{*}{$\mathbf{s t}^{* *}$} & & \multicolumn{2}{|c|}{ Staining } & \multirow{2}{*}{ Alter } & \multicolumn{2}{|c|}{ Staining } & \multirow[b]{2}{*}{ Alter } \\
\hline & & & & & & & & & & & $\mathbf{s t}^{*}$ & $\mathbf{s t}^{* * *}$ & & $\mathbf{s t}^{*}$ & $\mathbf{s t}^{* * *}$ & \\
\hline \multirow{3}{*}{$\begin{array}{l}\text { Su-KBB } \\
15 \% \text { of the } \\
\text { pigment } \\
\text { paste at } 150^{\circ} \\
\text { C for } 5 \text { min }\end{array}$} & Acrylic & 16.3 & 1840 & 1815.6 & 6 & $2-3$ & 2 & 4 & $3-4$ & 3 & 4 & $3-4$ & $3-4$ & 4 & 4 & 4 \\
\hline & $\begin{array}{c}\text { Polyester/ } \\
\text { viscose }\end{array}$ & 15.54 & 1250 & 1352.8 & 6 & 3 & $2-3$ & $3-4$ & 3 & $3-4$ & $3-4$ & 3 & 4 & 3 & 3 & $3-4$ \\
\hline & $\begin{array}{c}\text { Polyester/ } \\
\text { Acrylic }\end{array}$ & 11.74 & 580 & 498.5 & 6 & $2-3$ & 2 & 3 & $3-4$ & 3 & 3-4 & 3 & 4 & $3-4$ & 3 & 3 \\
\hline \multirow{3}{*}{$\begin{array}{l}\text { Su-KBB } \\
15 \% \text { of the } \\
\text { pigment } \\
\text { paste and } \\
2 \% \mathrm{GLU} \text { at } \\
150^{\circ} \mathrm{C} \text { for } \\
5 \mathrm{~min}\end{array}$} & Acrylic & 17.8 & 1980 & 1815.6 & 6 & 3 & $2-3$ & 3 & $3-4$ & 3 & 4 & 3 & 4 & $3-4$ & 3 & 4 \\
\hline & $\begin{array}{c}\text { Polyester/ } \\
\text { viscose }\end{array}$ & 15.78 & 1480 & 1352.8 & 6 & $3-4$ & 3 & 3 & 3 & 3 & 3-4 & 3 & 4 & 3 & 3 & $3-4$ \\
\hline & $\begin{array}{l}\text { Polyester/ } \\
\text { Acrylic }\end{array}$ & 12.3 & 780 & 498.5 & 6 & 3 & $2-3$ & 3 & 3 & 3 & 3 & $3-4$ & 3 & 3 & 3 & $3-4$ \\
\hline
\end{tabular}

Egypt.J.Chem. Special Issue (2017) 
on heat treatment, following the formation of cross-linked film the reactive groups form three dimensional networks that increase the stability of the film and enhance its durability to wet treatment. Pyridinium crosslink structure has been proposed to be derived from glutardialdehyde and proteins (Reaction scheme 4) [21].

Effect of mixing suspended-keratin based binder (Su-KBB) with the commercial binder (CB) on the fastness properties of the printed fabrics

The color strength and the fastness properties on using pigment printing pastes containing $\mathrm{Su}-\mathrm{KBB}$ (suspended-keratin based binder), CB (commercial binder) and different mixtures of them were assessed. The pastes were:

1. Paste containing the commercial binder CB SME-2 (Acrylate - based), under the commercially used conditions $(20 \%$ of the pigment paste under fixation temperatures 150
${ }^{\circ} \mathrm{C}$ for $5 \mathrm{~min}$ ).

2. Paste containing suspended-keratin based binder $\mathrm{Su}-\mathrm{KBB}$ prepared with the optimum condition ( $15 \% \mathrm{Su}-\mathrm{KBB}$, at $150^{\circ} \mathrm{C}$ for $\left.5 \mathrm{~min}\right)$.

3. Pastes containing different concentrations of Su-KBB and CB:

$75 \%$ CB $+25 \%$ Su-KBB (15 gm comm. +3.75 gm Su-KBB)

$50 \% \mathrm{CB}+50 \%$ Su-KBB (10 gm comm. +7.5 gm $\mathrm{Su}-\mathrm{KBB})$

$25 \%$ CB $+75 \%$ Su-KBB (5 gm comm. +11.25 gm $\mathrm{Su}-\mathrm{KBB}$ )

The color strength and the fastness properties of the printed fabrics of pigment printing pastes containing $\mathrm{Su}-\mathrm{KBB}, \mathrm{CB}$ and mixtures of them were assessed and tabulated in Table 7. Data of this table showed that, the color strength values of the Su-KBB, CB and different mixtures of them are almost similar to each other. Mixing between the CB and the Su-KBB

TABLE 7. Effect of mixing CB with Su-KBB on the color strength and fastness properties of the printed fabrics using Print M.D. Blue 2G.

\begin{tabular}{|c|c|c|c|c|c|c|c|c|c|c|c|c|c|c|c|c|}
\hline \multirow{4}{*}{$\begin{array}{l}\text { Type of } \\
\text { binder }\end{array}$} & \multirow{4}{*}{ Fabric } & \multirow{4}{*}{$\mathbf{K} / \mathbf{S}$} & \multirow{4}{*}{$\begin{array}{l}\text { Stiffness of } \\
\text { the printed } \\
\text { fabric }\end{array}$} & \multirow{4}{*}{$\begin{array}{l}\text { Stiffness } \\
\text { of the } \\
\text { unprinted } \\
\text { fabric }\end{array}$} & \multirow{4}{*}{$\begin{array}{l}\text { Light } \\
\text { fastness }\end{array}$} & \multirow{2}{*}{\multicolumn{2}{|c|}{ Rubbing }} & \multirow{2}{*}{\multicolumn{2}{|c|}{$\begin{array}{l}\text { Washing } \\
\text { Staining } \\
\end{array}$}} & \multirow{4}{*}{ Alter } & \multicolumn{6}{|c|}{ Perspiration } \\
\hline & & & & & & & & & & & & Acidic & & & Alkali & \\
\hline & & & & & & \multirow{2}{*}{ Dry } & \multirow{2}{*}{ Wet } & \multirow[b]{2}{*}{$\mathbf{s t}^{*}$} & \multirow[b]{2}{*}{$\mathbf{s t}^{* *}$} & & \multicolumn{2}{|c|}{ Staining } & \multirow{2}{*}{ Alter } & \multicolumn{2}{|c|}{ Staining } & \multirow[b]{2}{*}{ Alter } \\
\hline & & & & & & & & & & & $\mathrm{st}^{*}$ & $\mathrm{st}^{* *}$ & & $\mathrm{st}^{*}$ & $\mathrm{st}^{* *}$ & \\
\hline \multirow{4}{*}{$\begin{array}{l}\text { oे } \\
\text { dे } \\
\text { :ै }\end{array}$} & Polyester & 20.46 & 2150 & 605.2 & 6 & $3-4$ & $2-3$ & $3-4$ & $3-4$ & 3 & 4 & 4 & 4 & 4 & 4 & 3 \\
\hline & Viscose & 19.6 & 925.6 & 462.8 & 6 & $3-4$ & 3 & 4 & 4 & 4 & $4-5$ & $4-5$ & 4 & 4 & 4 & 4 \\
\hline & $\begin{array}{l}\text { Polyester / } \\
\text { viscose }\end{array}$ & 19.15 & 2000 & 1352.8 & 6 & $3-4$ & 3 & $3-4$ & $3-4$ & $3-4$ & 4 & 4 & 4 & 4 & 4 & 4 \\
\hline & $\begin{array}{c}\text { Polyester / } \\
\text { Acrylic }\end{array}$ & 16.5 & 1000 & 498.5 & 6 & 3 & $2-3$ & $3-4$ & $3-4$ & 3 & 4 & 4 & 4 & 4 & 4 & 3 \\
\hline \multirow{4}{*}{ 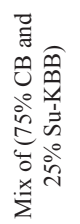 } & Acrylic & 14 & 2200 & 1815.6 & 6 & 3 & $2-3$ & 3 & $2-3$ & 3 & 4 & 4 & 4 & 4 & 4 & 4 \\
\hline & Polyester & 18.2 & 1850 & 605.2 & 6 & 3 & $2-3$ & $3-4$ & $3-4$ & 3 & 4 & $3-4$ & $3-4$ & 4 & 4 & 4 \\
\hline & Viscose & 18.7 & 770 & 462.8 & 6 & $3-4$ & 3 & 4 & 4 & 4 & 4 & 4 & 4 & 4 & $3-4$ & 4 \\
\hline & $\begin{array}{l}\text { Polyester / } \\
\text { viscose }\end{array}$ & 17.5 & 1650 & 1352.8 & 6 & $3-4$ & 3 & 4 & 4 & 4 & 4 & $4-5$ & $4-5$ & 4 & 4 & 4 \\
\hline \multirow{9}{*}{ 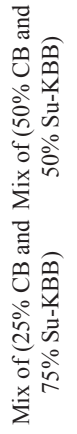 } & Polyester & 15.2 & 1750 & 605.2 & 6 & 3 & $2-3$ & $3-4$ & 4 & $3-4$ & 4 & 4 & 4 & 4 & 4 & 4 \\
\hline & Viscose & 17.4 & 650 & 462.8 & 5 & $3-4$ & 3 & $3-4$ & 4 & 4 & $4-5$ & 4 & 4 & 4 & 4 & 4 \\
\hline & $\begin{array}{l}\text { Polyester / } \\
\text { viscose }\end{array}$ & 16.5 & 1500 & 1352.8 & 6 & 3 & $2-3$ & 4 & $3-4$ & 4 & 4 & 4 & 4 & 4 & $3-4$ & 4 \\
\hline & $\begin{array}{l}\text { Polyester / } \\
\text { Acrylic }\end{array}$ & 14.3 & 760 & 498.5 & 6 & 3 & $2-3$ & 4 & $3-4$ & 3 & 4 & $3-4$ & $3-4$ & 4 & 4 & 4 \\
\hline & Acrylic & 15.8 & 1950 & 1815.6 & 6 & $2-3$ & 2 & $3-4$ & 3 & $3-4$ & 4 & $3-4$ & 4 & 3 & 3 & 4 \\
\hline & Polyester & 13.6 & 1700 & 605.2 & 6 & $2-3$ & 2 & 3 & 3 & $2-3$ & 4 & 4 & 4 & $3-4$ & 4 & 4 \\
\hline & Viscose & 18 & 620 & 462.8 & 6 & 3 & $2-3$ & 4 & 4 & 4 & 4 & 4 & 4 & $3-4$ & 4 & 4 \\
\hline & $\begin{array}{l}\text { Polyester / } \\
\text { viscose }\end{array}$ & 15.2 & 1500 & 1352.8 & 6 & 3 & $2-3$ & 4 & 4 & 4 & 4 & 4 & 4 & $3-4$ & $3-4$ & 4 \\
\hline & $\begin{array}{c}\text { Polyester / } \\
\text { Acrylic }\end{array}$ & 13.2 & 700 & 498.5 & 6 & $2-3$ & 2 & 4 & $3-4$ & 3 & 4 & $3-4$ & $3-4$ & 4 & 4 & 4 \\
\hline \multicolumn{4}{|c|}{$\mathrm{st}^{*}=$ staining on cotton, } & \multicolumn{3}{|c|}{$\mathrm{st}^{* *}=$ staining on wool, } & \multicolumn{10}{|c|}{ Alt. $=$ Alteration in color } \\
\hline
\end{tabular}


improved the dry and wet rubbing fastness of Su-KBB. It is also noticed that, the samples containing $\mathrm{CB}$ are stiffer than that containing the Su-KBB, so that mixing improved the stiffness of the printed samples with CB. Also all prints show good fastness to light, wash and perspiration. Thus, the mixing process managed to overcome the disadvantages of both $\mathrm{CB}$ and Su-KBB.

Rheological properties of the printing pastes containing $C B, S u-K B B$ and mixtures thereof

The rheological properties of the $\mathrm{CB}$ and $\mathrm{Su}-\mathrm{KBB}$ and their mixtures were assessed and summarized in Table 8 and Fig. 1. It is clear, from the rheograms in Fig. 1 that the chosen pastes were classified as a non-Newtonian pseudo plastic solution, since the relation between the shearing stress and rate of shear is not linear and the up and down flow curves are coincident [22]. This may enable the use of extremely fine screen gauges to give fine designs where the pseudo shows shear thinning [23], thus under the shearing action the paste flows, but when the applied force is released, the pastes retain the consistency on the surface of the fabric and this gives prints with defined edges this means if the viscosity (resistance of flow) of a paste is measured using a large applied force (shearing stress), which causes a high velocity of flow (rate of shear), the apparent viscosity is less than that of the same paste determined with a smaller force and a slower rate of flow. Varied locations of rheograms with respect to rate of shear axis show differences in their viscosity as it is obvious in Table 8 .

It is clear from data of Table 8 and Fig. 1 that printing pastes containing the prepared Su$\mathrm{KBB}$ are characterized by the same rheological properties of their corresponding pastes containing

TABLE 8. The apparent viscosity of the pigment pastes containing the CB, Su-KBB and mixtures of them.

\begin{tabular}{|c|c|c|c|c|c|}
\hline \multirow[b]{2}{*}{$\begin{array}{l}\text { Rate of } \\
\text { shear } \\
\left(\mathrm{cm}^{-1}\right)\end{array}$} & \multicolumn{5}{|c|}{ Apparent viscosity of pastes (poise): } \\
\hline & $\begin{array}{l}\text { Commercial } \\
\text { binder }(20 \mathrm{~g} \\
/ 100 \mathrm{~g} \text { paste })\end{array}$ & $\begin{array}{l}\text { suspended-keratin } \\
\text { binder (15g / 100g } \\
\text { paste) }\end{array}$ & $\begin{array}{l}\text { Mix of them } \\
\text { ( } 75 \% \text { com. }+ \\
25 \% \text { suspended- } \\
\text { keratin) }\end{array}$ & $\begin{array}{c}\text { Mix of them } \\
\text { ( } 50 \% \text { com. }+50 \% \\
\text { suspended-keratin) }\end{array}$ & $\begin{array}{l}\text { Mix of them } \\
\text { ( } 25 \% \text { com. }+75 \% \\
\text { suspended- } \\
\text { keratin) }\end{array}$ \\
\hline 0.03 & 10,775 & 8250 & 9230 & 8200 & 6120 \\
\hline 0.07 & 8435 & 5225 & 7400 & 6150 & 5500 \\
\hline 0.14 & 4700 & 3556.5 & 4300 & 3300 & 3000 \\
\hline 0.17 & 3900 & 2600 & 3220 & 3000 & 2500 \\
\hline 0.2 & 3350 & 2000 & 2700 & 2600 & 2100 \\
\hline 0.24 & 2960 & 1850 & 2500 & 2300 & 1850 \\
\hline
\end{tabular}

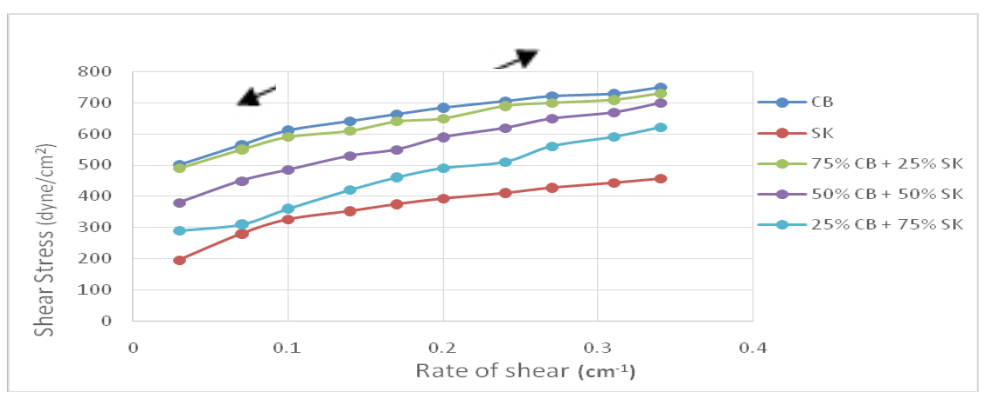

Fig. 1. Rheograms of CB, Su-KBB and mixtures there from $20 \% \mathrm{CB}$ (20gm on the pigment paste)

$15 \% \mathrm{Su}-\mathrm{KBB}$ (15gm on the pigment paste).

$75 \%$ CB $+25 \%$ Su-KBB (15 gm comm. +3.75 gm Su-KBB)

$50 \%$ CB $+50 \%$ Su-KBB (10 gm comm. +7.5 gm Su-KBB)

$25 \%$ CB $+75 \%$ Su-KBB (5 gm comm. + 11.25 gm Su-KBB)

Egypt.J.Chem. Special Issue (2017) 
the commercial binder which is based on acrylate where both of them are characterized by a nonNewtonian pseudoplastic behavior. Furthermore, mixing the aforementioned two pastes does not affect the rheological character of the paste, as it remains the same (i.e. non-Newtonian pseudoplastic) irrespective of the ratio of mixing.

Fastness properties of the different pigment colors using $\mathrm{Su}-\mathrm{KBB}$

Considering the optimum condition of preparing S- KBB and the optimum condition of the pigment paste preparation, Su-KBB utilized in this study using two types of pigment printing namely; Print M.D. Blue $2 \mathrm{G}$ and Red GRL.<smiles>C=CC(=O)Nc1ccc(N=NC2=C(O)C3C=CC=CC3C(S(=O)(=O)O)=C2)cc1</smiles>

\section{Structure 2. Red GRL pigment.}

The color strength and fastness properties, of Su-KBB using the two types of pigment printing, were monitored in Table 9. Data of Table 9 showed that results of the color strength and fastness properties of the printed fabrics using Su-KBB, with the blue pigment were almost comparable to those with red pigment and almost take the same trend only small differences in the stiffness of the prints were observed. It may be concluded that $\mathrm{Su}-\mathrm{KBB}$ can be used with different pigment colors and on different fabrics.

\section{Water absorbency of the binder films}

Water absorption of soluble - keratin film, suspended-keratin film, and commercial film is shown in Fig. 2.

This figure shows that, the water absorption of the suspended-keratin based binder film is higher than that of the commercial binder. This could be attributed to the presence of polar groups along keratin macromolecules viz. $-\mathrm{NH} 2,-\mathrm{OH}$, and $\mathrm{COOH}$ groups which are able to form hydrogen bonds with water molecules [24].

\section{Thermal properties}

The thermal behaviour (DSC and TGA) of the SuKBB extracted from wool or feather as well as the CB were assessed. Results of this study were shown in Fig. 3 and Table 10. Also the glass transition temperature of the $\mathrm{Su}-\mathrm{KBB}$ and the CB was shown in the DSC charts in Fig. 4 and 5.

Figure 3 elucidated that, $\mathrm{CB}$ exhibits high thermal stability until $300{ }^{\circ} \mathrm{C}$. It has been reported that poly acrylate based polymer develop anhydride ring structures as a result of a dehydration process at high temperatures (c.f. reaction scheme 5) [25]. A further increase in the temperature of degradation causes the formation of chain fragments with

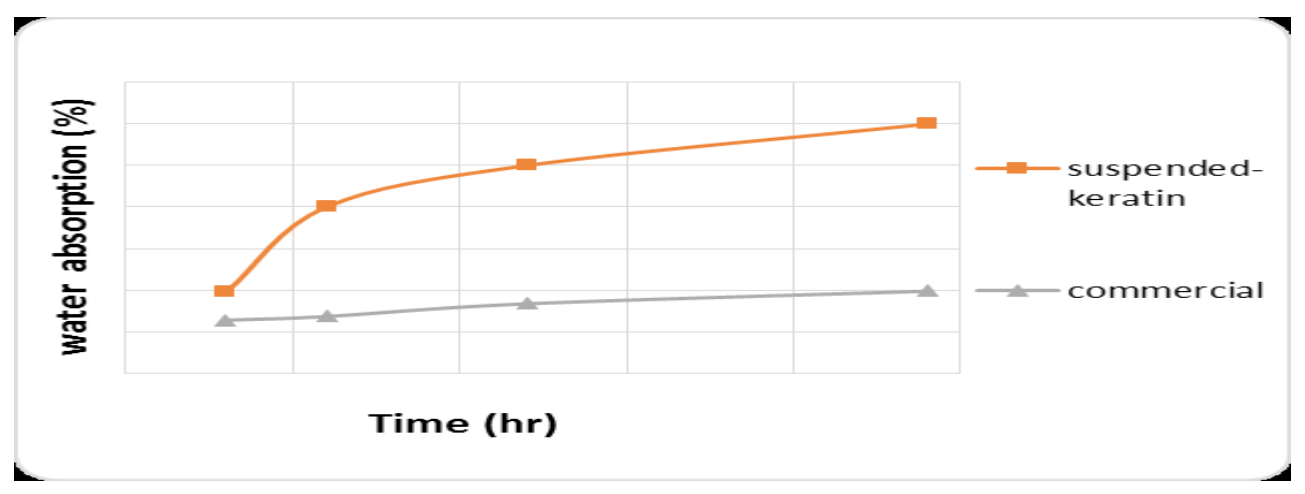

Fig. 2 Water absorption of the CB, So-KBB and Su-KBB.

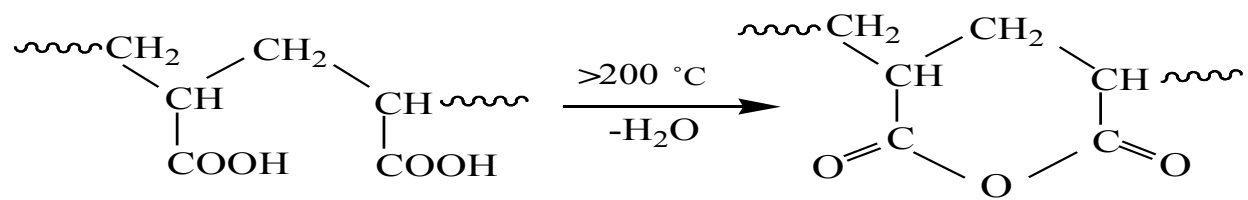

Reaction scheme 5. Condensation reaction of polyacrylate at high temperature. 
TABLE 9. Color strength and fastness properties of the printed fabrics using Blue $2 \mathrm{G}$ and Red GRL using Su-KBB extracted from wool.

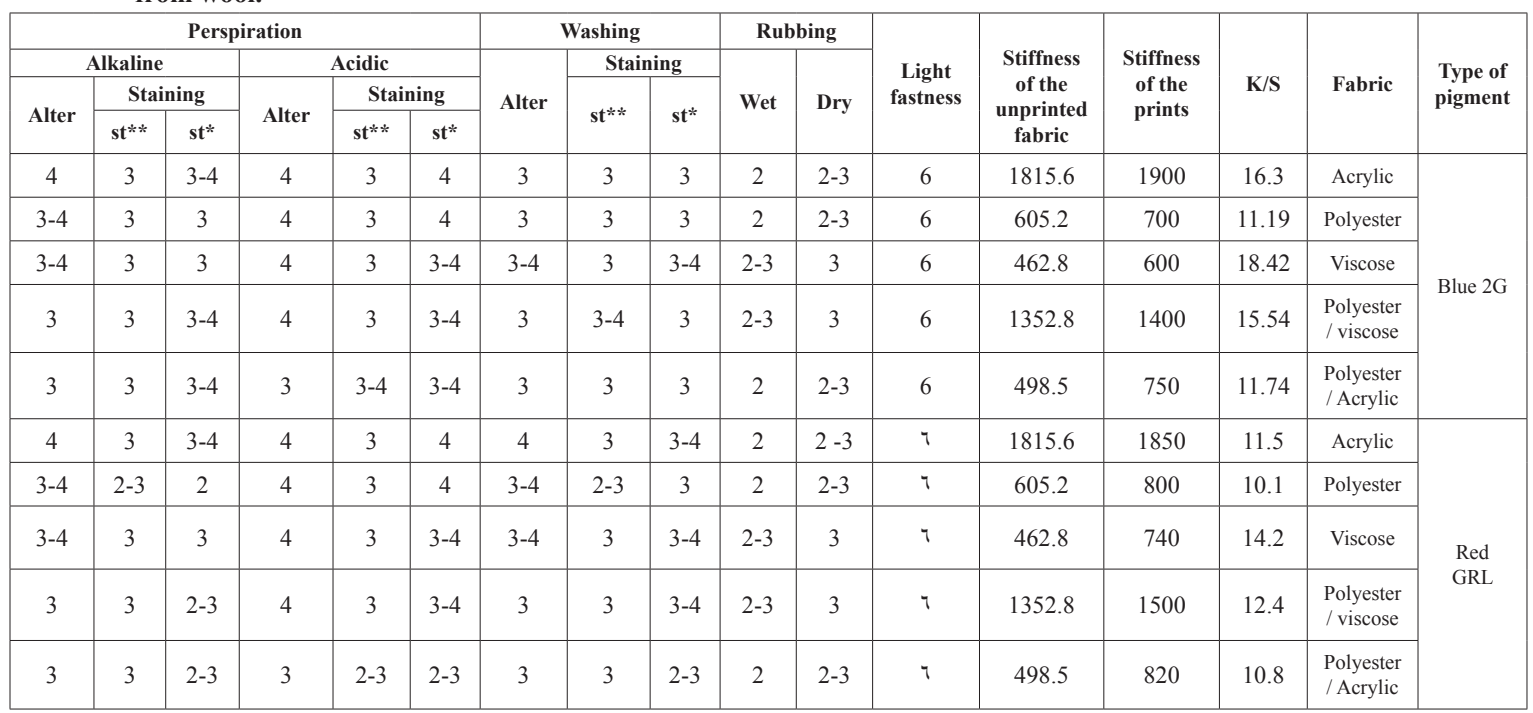

TABLE 10. The effect of temperature on the decomposition of Su-KBB and the commercial binder.

\begin{tabular}{|ccc|}
\hline Loss in weight & \multicolumn{2}{c|}{ Decomposition temperature of (C) } \\
Commercial & Su-KBB \\
\hline $10 \%$ & 322 & 182 \\
$20 \%$ & 341 & 207 \\
$30 \%$ & 355 & 241 \\
$40 \%$ & 368 & 284 \\
$50 \%$ & 384 & 308.6 \\
$60 \%$ & 397 & 354.7 \\
$70 \%$ & 415 & 514 \\
$80 \%$ & 467 & 600 \\
$90 \%$ & 572 & - \\
$96.3 \%$ & 648.5 & - \\
\hline
\end{tabular}

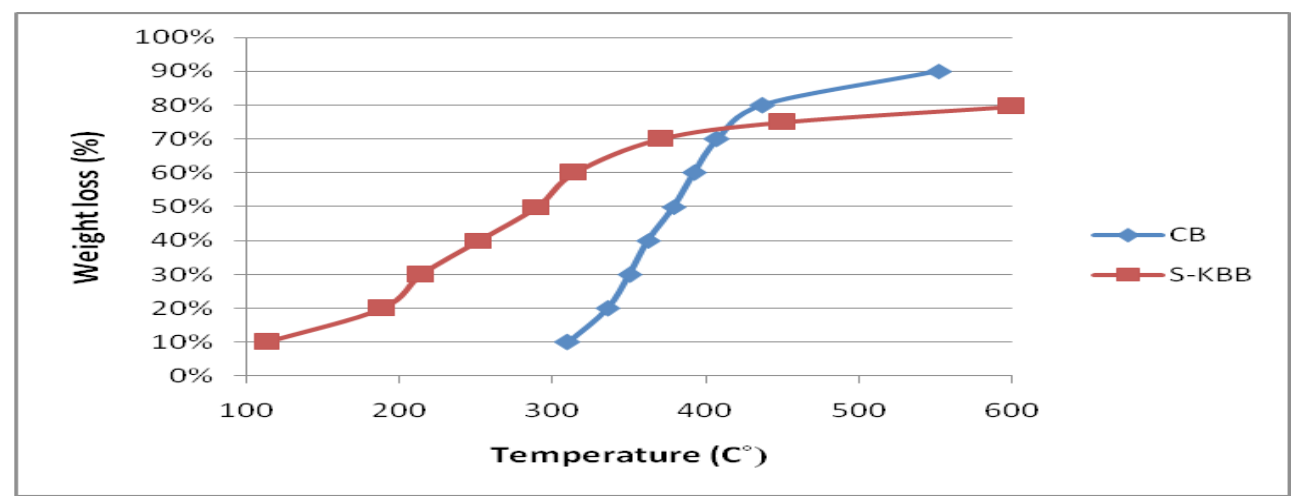

Fig. 3. Relation between the decomposition temperature and the loss in weight. 
TABLE 11. Elucidation of the initial decomposition temperatures, maximum rate of decomposition and $\mathrm{Tg}$ of both the Su-KBB and CB.

\begin{tabular}{|c|c|c|c|c|c|}
\hline \multirow[b]{2}{*}{ Binder type } & \multirow{2}{*}{$\begin{array}{l}\text { Initial decomposition } \\
\text { temperature (IDT) (C) }\end{array}$} & \multicolumn{3}{|c|}{ Maximum rate of decomposition } & \multirow[b]{2}{*}{$\mathbf{T g}$} \\
\hline & & $\begin{array}{l}\text { Temp. } \\
\text { (C) }\end{array}$ & $\begin{array}{c}\text { Weight loss } \\
\%\end{array}$ & $\begin{array}{c}\text { Rate } \\
\text { Weight } \% \text { / min }\end{array}$ & \\
\hline $\mathrm{CB}$ & 238 & 349.5 & 46.45 & 1.33 & 59.7 \\
\hline Su-KBB & 130 & 300 & 26.46 & 0.9 & 109.2 \\
\hline
\end{tabular}

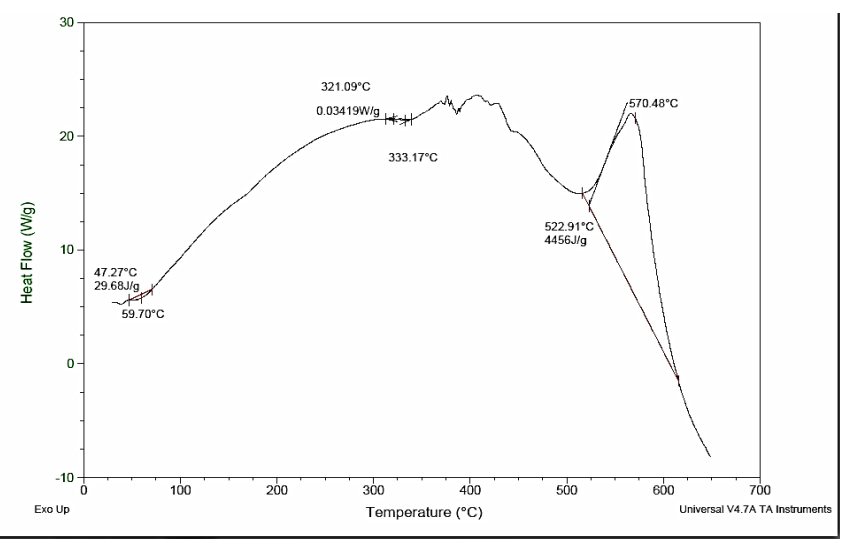

Fig. 4. DSC chart of the CB.

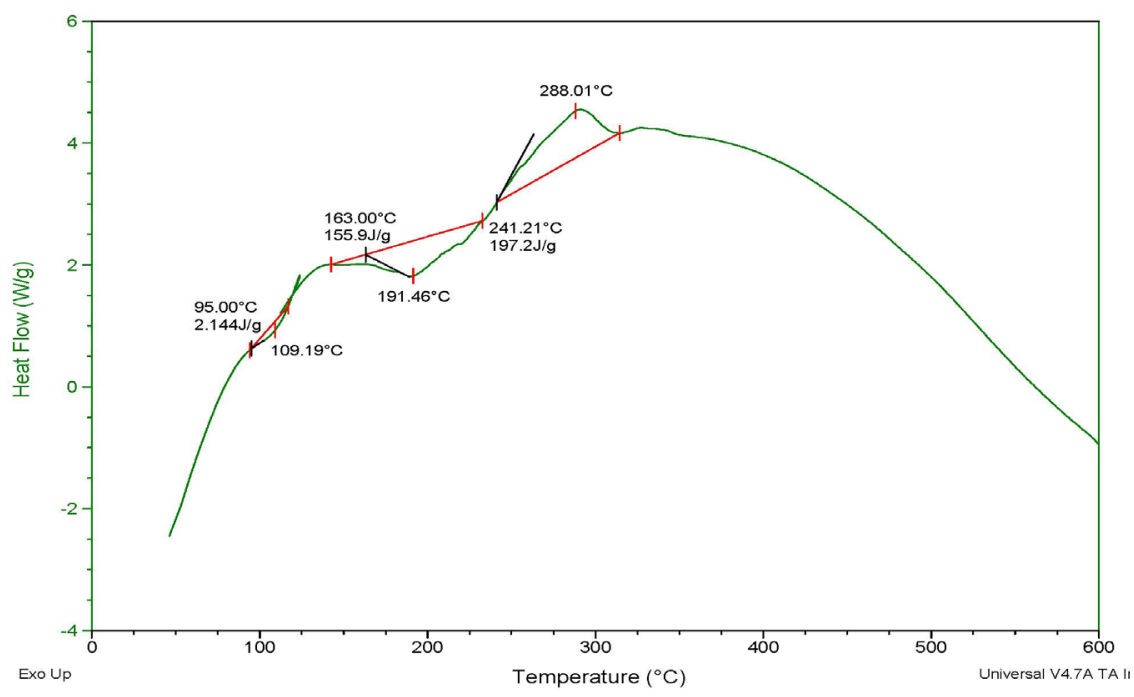

Fig. 5. DSC Chart of Su-KBB. 
anhydride rings or acid groups, together with various minor volatile products [26].

On the other hand, the used Su-KBB exhibits less thermal stability than the $\mathrm{CB}$ at low temperatures. But at higher temperatures the thermal stability of Su-KBB increased gradually, this could be explained by the presence of several active groups in the Su-KBB viz., (Carboxylic, amino, and hydroxyl groups) forming new crosslinks which hinder its degradation at higher temperature.

In case of commercial binder residual weight percentage at maximum temperature (which is 648.5

\section{${ }^{\circ}$ ) is $3.73 \%$.}

In case of suspended-keratin binder, residual weight percentage at maximum temperature (which is $600^{\circ} \mathrm{C}$ ) is $20.43 \%$.

Data of Table 11 showed that, the initial decomposition temperature of the $\mathrm{CB}$ is higher than that of the Su-KBB. Thus, the thermal stability of the $\mathrm{CB}$ is more than $\mathrm{Su}-\mathrm{KBB}$ as it is proved from Fig. 3 and Table 10. It is also noticed that the maximum rate of decomposition and the maximum weight loss of both the binders are different. This is in harmony with the data in Fig. 2 , where the rate of decomposition of $\mathrm{Su}-\mathrm{KBB}$ is lower than that of the $\mathrm{CB}$. The Table also revealed

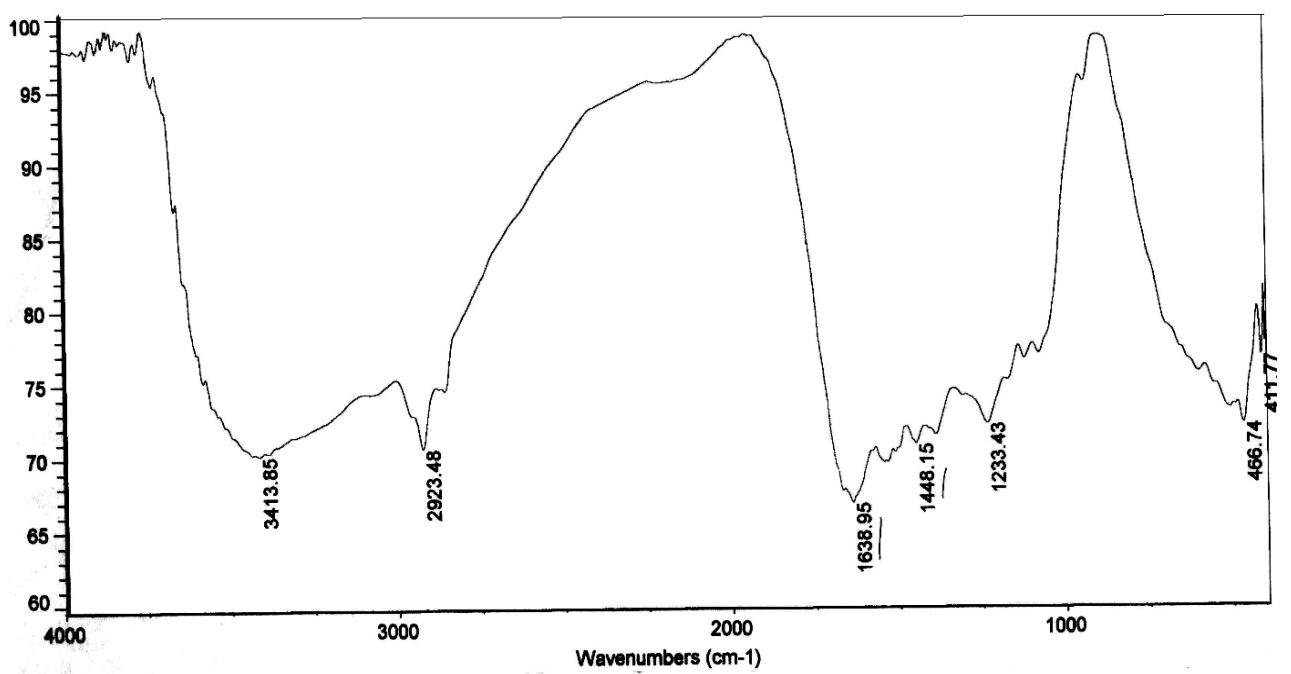

Fig. 6. IR chart of native wool.

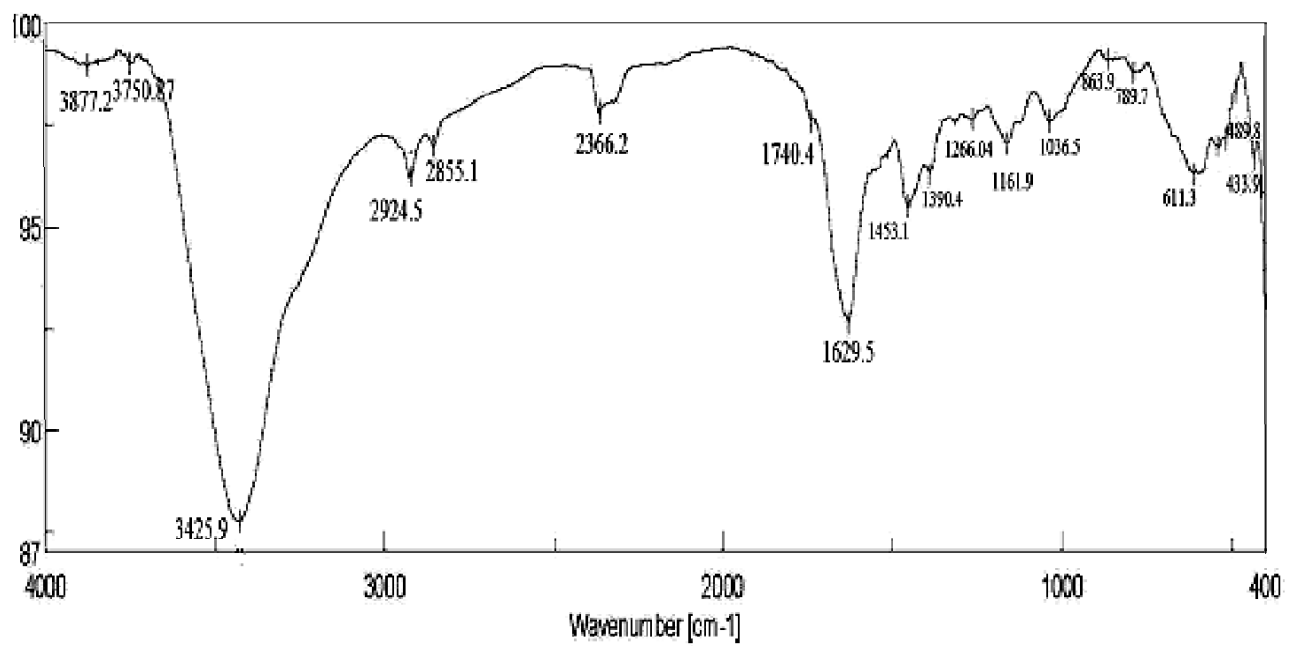

Fig. 7. IR chart of suspended-keratin. 


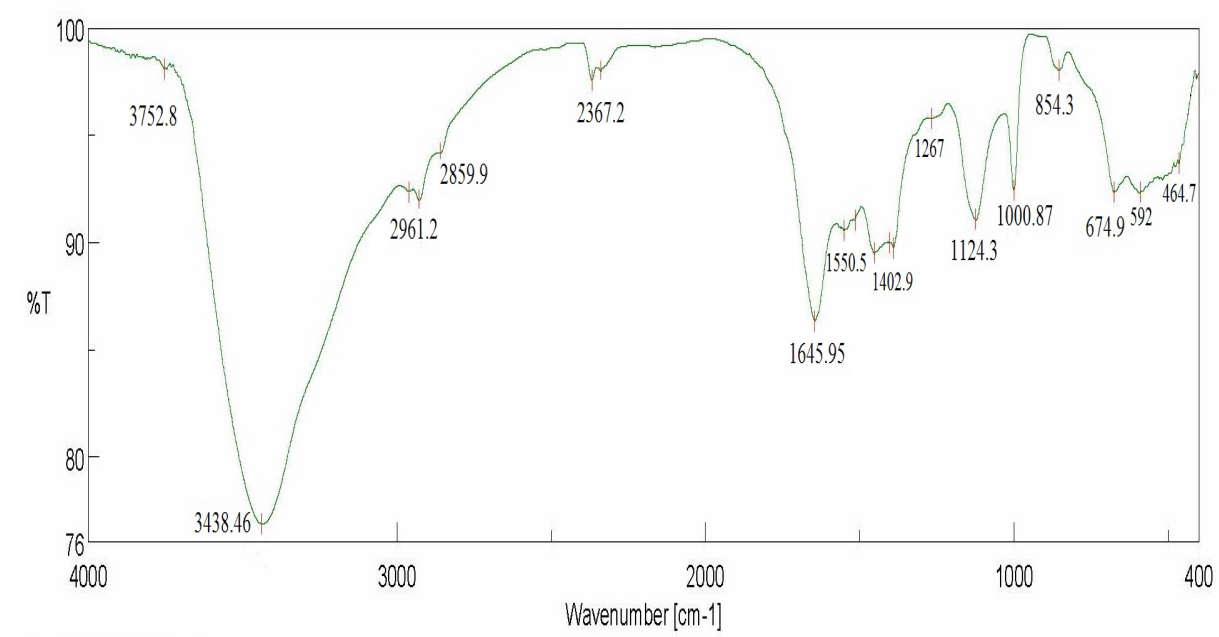

Fig. 8. IR chart of soluble keratin.

the glass transition temperature as shown in the DSC-TGA charts present in Fig. 4 \& 5 and it is noticed that $\mathrm{Tg}$ of $\mathrm{Su}-\mathrm{KBB}$ is higher than that of $\mathrm{CB}$.

\section{Infrared (IR) Spectrometry}

Fourier Transform Infrared (FTIR) spectrometry was used to monitor any change in the chemical composition of wool after being dissolved and changed into suspension. The IR spectroscopy in Fig. $6-8$ revealed that, there was almost no change in the main chemical structure of wool after being solubilized and recovered as suspended-keratin. This structure was obvious by the presence of $\mathrm{N}$ $-\mathrm{H}$ stretching vibration band around $3400 \mathrm{~cm}^{-1}$ or that of carbonyl group around $1630 \mathrm{~cm}^{-1}$. Nevertheless, there was a remarkable increase in the intensity of the bands depending on the condition of preparation of the suspendedkeratin. This can be attributed to the presence of urea in the aqueous suspension solution used for preparation of suspended-keratin. These results also were in harmony with the results of the elemental analysis of Table 11, which showed an increase in the percentage of the nitrogen element of the suspended-keratin. It is noteworthy to mention that the FTIR chart of soluble keratin (not the suspended in urea solution) clarifies that the intensity of $\mathrm{N}-\mathrm{H}$ stretching vibration and carbonyl stretching vibration band are more intense than their analogue bands in raw wool. This is could be attributed to the limited breaking of the peptide bonds of the polypeptide chains that cause the formation of new amino groups and carbonyl groups.

\section{Elemental analysis}

The carbon, hydrogen, sulphur and nitrogen contents of the used suspended-keratin as well as raw Egyptian wool fleece were measured and tabulated in Table 12. That table showed that there is appreciable change in the percentage of hydrogen and carbon and remarkable change in percentage of sulphur as a result of the technique of preparation which depend on the fact that wool is dissolved by breaking the polypeptide chains which consequently causes liberation of $\mathrm{CO}_{2}$ (decarboxylation) liberation of $\mathrm{NH}_{3}$ (deamination) or liberation of $\mathrm{H}_{2} \mathrm{~S}$ (desulphhydration) [6]. On the other hand, it was obvious that the percentage of nitrogen increased in the suspended-keratin and this may be attributed to the preparation method where the suspension of keratin takes place in $2.5 \%$ urea solution with homogenous stirring which compensates the amount released during the hydrolysis process.

TABLE 12. Elemental analysis of the raw wool and suspended keratin.

\begin{tabular}{|c|c|c|c|r|}
\hline Sample & $\mathbf{C \%}$ & $\mathbf{H \%}$ & $\mathbf{S \%}$ & $\mathbf{N \%}$ \\
\hline $\begin{array}{c}\text { Raw wool } \\
\text { fleece }\end{array}$ & 45.81 & 10.8 & 2.9 & 14.60 \\
\hline $\begin{array}{c}\text { Feather } \\
\text { Suspended- } \\
\text { keratin }\end{array}$ & 44.1 & 9.8 & 3.5 & 13.9 \\
\hline
\end{tabular}

\section{Conclusion}

Keratin was extracted by dissolution of Egyptian wool fleece and feather in alkaline solution of alkali metal hydroxide in presence 
of swelling and reducing agents without severe degradation of the keratin macromolecules. The solubilized keratin is precipitated in a coagulating bath, and the precipitate was collected by filtration with polyester cloth. The precipitate is dried overnight and grounded to powder form and then suspended in a solution of sodium hydroxide and urea. The suspended-keratin obtained is used as a binder in the process of the pigment printing. The data of the colour strength of the printed fabric with the Su-KBB (suspended-keratin based binder) and the $\mathrm{CB}$ (commercial binder) are comparable to each other. Fastness properties to rubbing of the printed fabric using $\mathrm{CB}$ are higher than those printed using Su-KBB and this problem was solved by applying cross-linkers to the pigment pastes containing Su-KBB. Mixing of Su-KBB and $\mathrm{CB}$ avoids some disadvantages of the $\mathrm{CB}$ (high stiffness values) and Su-KBB (low fastness to rubbing). Pigment pastes containing suspended-keratin based binder ( $\mathrm{Su}-\mathrm{KBB}$ ) found to have good rheological properties which enabled this type of binders to be used in silk screen or roller printing methods and classified as nonNewtonian pseudoplastic solutions. Chemical and spectroscopic analyses of suspended-keratin based binder showed that the primary structure of wool or feather was not affected as a result of its dissolution and the molecular weight of extracted keratin was found to be 2-9 KDa.

\section{References}

1. Solangi1 W.H., Noonari Z.A., Channa A.A., Khan M.Q. and Siyal A.B., Influence of binders and thickeners of pigment printing paste on light fastness and crocking fastness of the fabric. International Journal of Science and Research (IJSR), 3 (5), 1024 (2014).

2. Tabba A.H. and Hauser P., Effect of cationic pretreatment on pigment printing of cotton fabric, Textile Chemistry and Colorist \& American Dyestuff Reporter, 32, 30 (2000).

3. Pauling L., Corey R.B. and Bronson H.R., Dimensions of polypeptide chains. Proc. Nat. Acad. Sci. USA, 39, 253 (1953).

4. Rippon J.A; "Wool Dyeing, chapter 1: The Structure of Wool"; edited by David M. Lewis, published by the Society of Dyers and Colourists, 6, (1992)

5. Yin J., Rastogi S., Terry A.E. and Popescu C., Self-organization of oligopeptides obtained on dissolution of feather keratins in superheated water. J. Biomacromolecules, 8, 800 (2007).

6. Abou El-Kheir A, Mowafi S, Abou Taleb M and El-Sayed H, Preparation and characterization of keratin-polyvinyl alcohol composite film. Egyptian J. of Chemistry, 55, 491 (2012).

7. Mowafi S., Abou El-Kheir A., Abou Taleb M. and El-Sayed H., keratin-and-sericin-state-of-the-artand-future-outlook. J. Der Pharma Chemica, 8 22, (2016).

8. Zhang S., Yuan B.L., Li F.X., Yu J.Y., and Gu L.X, structure and properties of novel cellulose fibre. Chemcal Fibres International. 3, 171 (2008).

9. Jing L.V., Min X. and Shuilin C., Synthesis and characterization of nonformaldehyde releasing and low temperature curable binder, AATCC Review, 3(6), 29 (2003).

10. Menter J. M. and Hatch K. L., Clothing as solar radiation protection. Current Problem in Dermatology, 31, 50 (2003).

11. AATCC Technical Manual, Method 8, (1989), 68, 23 (1993).

12. AATCC Technical Manual, Method 36, (1972), 68, 23, (1993).

13. AATCC Technical Manual, Method 15, (1989), 68, 30 (1993).

14. AATCC Technical Manual, Method 16A, (1989), Color fastness to light: carbon - Arc lamb continuous light 68, 33 (1993).

15. ASTM method $1388-96$, standard test method for stiffness of fabric, Annual book of ASTM standards, 7.01320 (2002).

16. Berbu M. and Spirdon L., Thermal degradation of keratin waste, J. Analytical and Applied Pyrolysis, 91(2), 288 (2011).

17. Gooding D. M. and Kaufman G. K., Tribocharging and the Triboelectric Series. Encyclopedia of Inorganic and Bioinorganic Chemistry, 1 (2014).

18. Park O., Lee S., Joh H., Kim J. K. Kang P., Lee, J. H. and $\mathrm{Ku}$ B., Effect of functional groups of carbon nanotubes on the cyclization mechanism of polyacrylonitrile (PAN). Polymer, 53(11), 2168 (2012). 
19. Bajaj P. and M. Kumari S., Structural investigations on hydrolyzed acrylonitrile terpolymers. European Polymer Journal, 24, 275 (1988).

20. Silva J.S.M., Sousa F., Gübitz G. and Cavacopaulo A., Chemical modifications on proteins using glutaraldehyde. Food Technology and Biotechnology, 42, (1), 51, (2004).

21. Hermansson G.T., "Bioconjugate Techniques". (Academic San Diego, CA, USA), 286 (1996).

22. El -Shemy N., Haggag K., El-Kharady and ElSayed H., Synthesis and applications of nano binder based on plant oils. J. Natural Fibre, 14(1), p. 10, (2017).

23. Kruyt H.R.; "Colloidal Science”; El Sevier Publisher Co., London, 21 (1949).

24. Abou El-Kheir A., Popescu C., Mowafi S., Salama M. and El-Sayed H., Physico-chemical properties of keratin-polyvinyl alcohol composite. Fibers and Polymers, 16, 537 (2015).

25. Nicholson J. W., Wassan E. A., and Wilson A. D., Thermal behaviour of films of partially neutralized poly (acrylic acid). 3: Effect of magnesium and calcium ions. British Polymer Journal, (20), 97 (1988).

26. McNeill I.C. and Sadeghi S.M.T., Thermal stability and degradation mechanisms of poly (acrylic acid) and its salts: part 1-poly (acrylic acid)"Polymer Degradation and Stability. 29(2), 233 (1990).

\section{تحضير وتقييم مواد ربط من الكيراتين المعلق وإستخدامها فى الطباعة على الاقمشة} الصناعية بالمخضبات وتصن

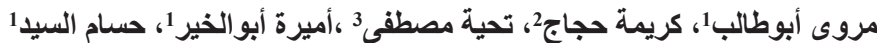

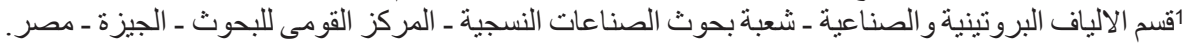

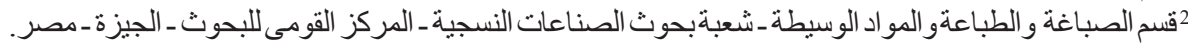

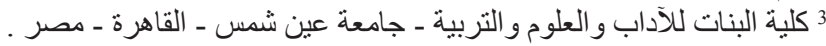

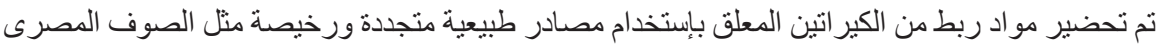

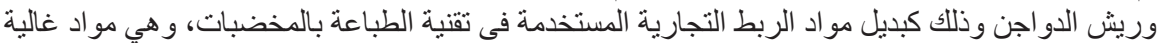

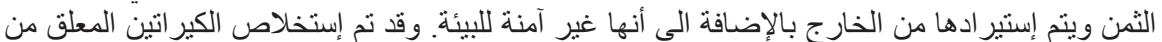

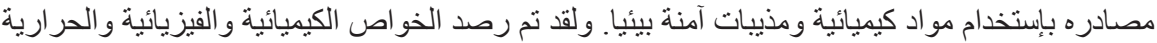

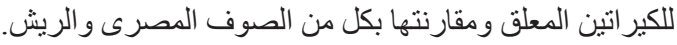

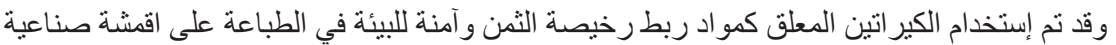

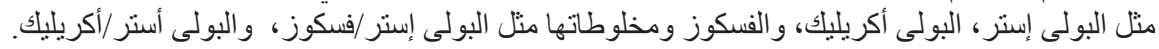

وتم تحضير تركيزات مختلفة من الكير اتين و إضافته إلى عجينة الطباعة بنسب مختلفة وفي وجود مو اد قادرة على تكوين روابط عرضية فى عجينة الطباعة.

كما تم قياس شدة الضوء للعينات المطبو عة وقياس ثبات الألو ان ضد العديد من العو امل مثل (الإحتكالك

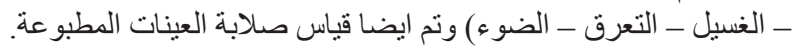

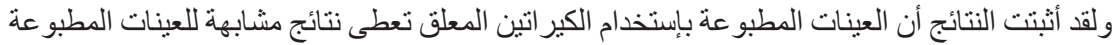

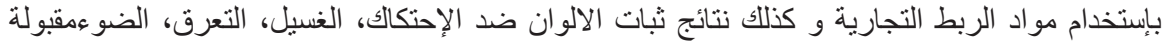

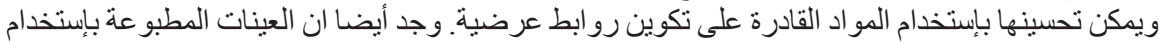

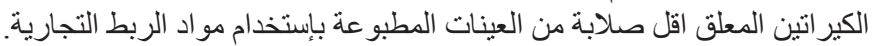

